\title{
Sustainability analysis of tomato jellyfish (Crambione mastigophora) fisheries resources management in Saleh Bay Waters, Sumbawa Island, Indonesia
}

\author{
EVRON ASRIAL ${ }^{1, \bullet}$, MUHAMMAD MARZUKI ${ }^{2}$, HAMID $^{3}$, RULY ISFATUL KHASANAH ${ }^{4}$ \\ ${ }^{1}$ Department of Fisheries Resources Utilization, Faculty of Fishery, Universitas 45 Mataram. Jl. Imam Bonjol 45, Mataram 83239, West Nusa \\ Tenggara, Indonesia, ”email: evronasrial81@gmail.com, ulick.isfatul@gmail.com \\ ${ }^{2}$ Department of Aquaculture, Faculty of Agriculture, Universitas Mataram. J1. Majaphit 62, Mataram 83115, West Nusa Tenggara, Indonesia \\ ${ }^{3}$ Department of Aquaculture, Faculty of Fishery, Universitas 45 Mataram. Jl. Imam Bonjol 45, Mataram 83239, West Nusa Tenggara, Indonesia \\ ${ }^{4}$ Marine Science Program, Faculty of Science and Technology, Universitas Islam Negeri Sunan Ampel. Jl. Ahmad Yani 117, Surabaya 60237, East Java, \\ Indonesia
}

Manuscript received: 28 November 2020. Revision accepted: 5 January 2021.

\begin{abstract}
Asrial E, Marzuki M, Hamid, Khasanah RI. 2021. Sustainability analysis of tomato jellyfish (Crambione mastigophora) fisheries resources management in Saleh Bay Waters, Sumbawa Island, Indonesia. Biodiversitas 22: 512-520. The tomato jellyfish (Crambione mastigophora) or gullung (local term), is endemic in Saleh Bay, Sumbawa Island, Indonesia and has been utilized as an additional livelihood by fishermen for last two decades. Its commonly caught by 2-4 fishermen/boat using scoop net, wooden fishing vessels, and lamps as attractors and collectors of jellyfish. This study aims to determine the sustainability of jellyfish fisheries management. A survey-dependent method with sampling, observation, dialogue, and documentation techniques was applied for data compilation. The rapid appraisal for jellyfish fisheries - six dimensions (Rapjellyfish-6D), based on Rapfish technique, is utilized for analysis of the sustainability status of jellyfish fisheries management. This paper describes the sustainability analysis results for two of the six dimensions of jellyfish fisheries management, namely the technological dimension (13 attributes) as an input factor and the economic dimension as an output factor (14 attributes). At present, around 8-30 baskets/boat/day of jellyfish mouth-arms are being sold to the buyers in Saleh Bay. This catch's profit is divided between the fishermen ( 3 parts) and the boat owner ( 2 parts). The analytical results show the revenue per cost ratio (R/C Ratio) as 4.75 which means that every 1.00 Indonesian Rupiah (IDR) the cost of catching jellyfish will generate IDR 4.75. The breakeven point (BEP)Price is IDR 13,158 and BEPProduction is 3.13 and 8.33 baskets/trip for the assumed price of IDR 80,000 and IDR 30,000. The technological (36.13\%) sustainability status and economic (49.64\%) dimension is Less Sustainable. The leverage analysis results indicate that the group of sensitive attributes in the technological and economic dimensions, respectively, consists of 5 attributes and 3 attributes. All sensitive attributes have an impact on the low value of management sustainability. The sustainability of jellyfish fisheries management in Saleh Bay has been supported by a choice of environmentally friendly fishing methods. Besides, the mouth-arm price is formed from an oligopsony market system that is not profitable for fishermen. It is suggested to the village government to build an integrated and environmentally friendly scyphozoan facility to neutralize the liquid waste generated from scyphozoan processing.
\end{abstract}

Keywords: Gullung, oligopsony, Rapjellyfish-6D, scoop net

\section{INTRODUCTION}

Crambione mastigophora or tomato jellyfish is a species of edible jellyfish, which are classified as true jellyfish because they belong to the Scyphozoa family (Figure 1). Jellyfish are classified as zooplankton (Brotz et al. 2012; Condon et al. 2012) or mega-zooplankton (Schroeder et al. 2014), and are also commonly called a gelatinous macro-zooplankton, jelly plankton (Condon et al. 2012; Brotz and Pauly 2012; Brotz et al. 2012), medusa, plural medusae (Miranda et al. 2012), scyphomadusae (Manuputty 1988) or simply named as scyphozoan (Perissinotto et al. 2013; Asrial et al. 2015a). Indonesia was the first country to use the scyphozoan for culinary food, even before 1950 (Brotz 2016).

Southeast Asia is known as a primary producer of edible jellyfish (Figure 2) and as major supplier to China. Southeast Asian countries that routinely supply semi-dried salted jellyfish products to China are Indonesia, Malaysia, the Philippines, Thailand, Myanmar, and Vietnam. Indonesia is the earliest country to use scyphozoan for culinary even before 1950 (Brotz 2016).

Indonesia and Thailand's coastal waters have the highest number of Scyphozoa species in Southeast Asia, each with 5 species, which come from 6 families (Brotz 2016; Asrial et al. 2018). Species belonging to Catostylidae family (4 species) are the most dominant, and 3 species of this family breed in Indonesian coastal waters. Around ten species of scyphozoan found in Indonesian coastal waters (Asrial et al. 2018).

Tomato jellyfish species are found in the waters of Malay Archipelago, Java and Truk Island (Omori and Nakano 2001), Indonesia (Asrial et al. 2015a), and northwestern Australia (Keesing et al. 2016). The Indian Ocean and Saleh Bay's coastal waters are the habitat for tomato jellyfish (Asrial 2015a). Fishermen carry out tomato 
jellyfish fisheries in Prigi Bay (Trenggalek, East Java), Muncar (Banyuwangi, East Java), and Saleh Bay (Sumbawa, West Nusa Tenggara) (Asrial et al. 2015a). Only in the Saleh Bay waters, tomato jellyfish consists of red and white (pers. com. Supardi 2018). Tomato jellyfish are very common, and it lives and breeds in the waters of Saleh Bay (Asrial et al. 2015a). Saleh Bay coastal communities locally call it "gullung".

The existence of scyphozoans in Saleh Bay has been known by fishermen since 2002, and began to be caught in 2006 as a fishing activity for fishermen's household income source (Asrial 2015). Catching jellyfish using scoop net (fishing gear), and the mouth-arm of jellyfish are processed into semi-dried salted jellyfish on the coastal mainland of Saleh Bay (Asrial 2015). The fishing and processing activities of scyphozoan in Saleh Bay have a very large multiplier effect on the economic activities of coastal communities, especially public service businesses.

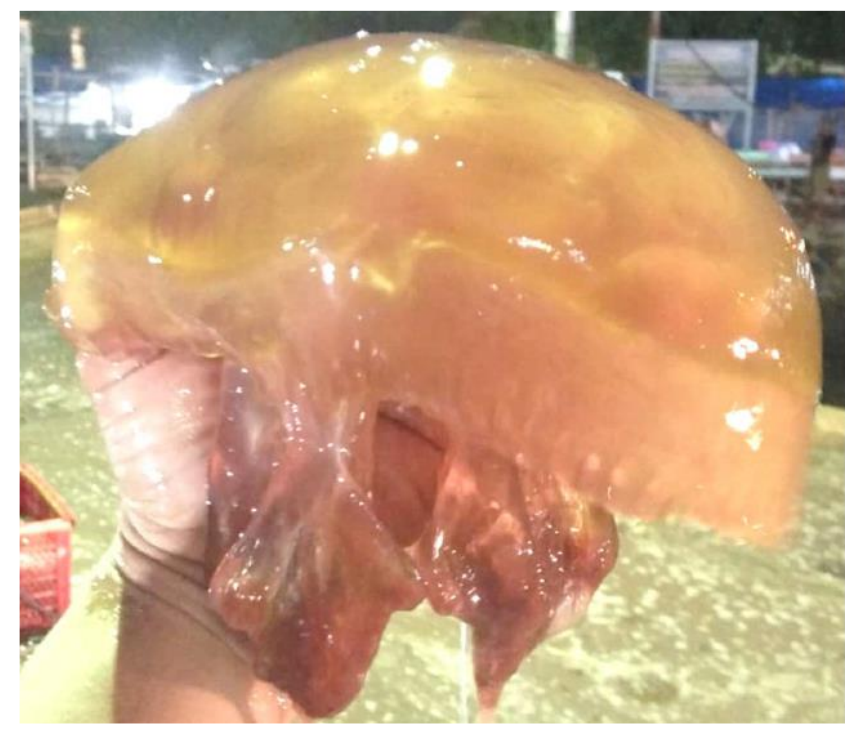

Figure 1. Tomato jellyfish (Carmbione mastigophora Maas, 1903 from the Saleh Bay Waters, Sumbawa Island, Indonesia

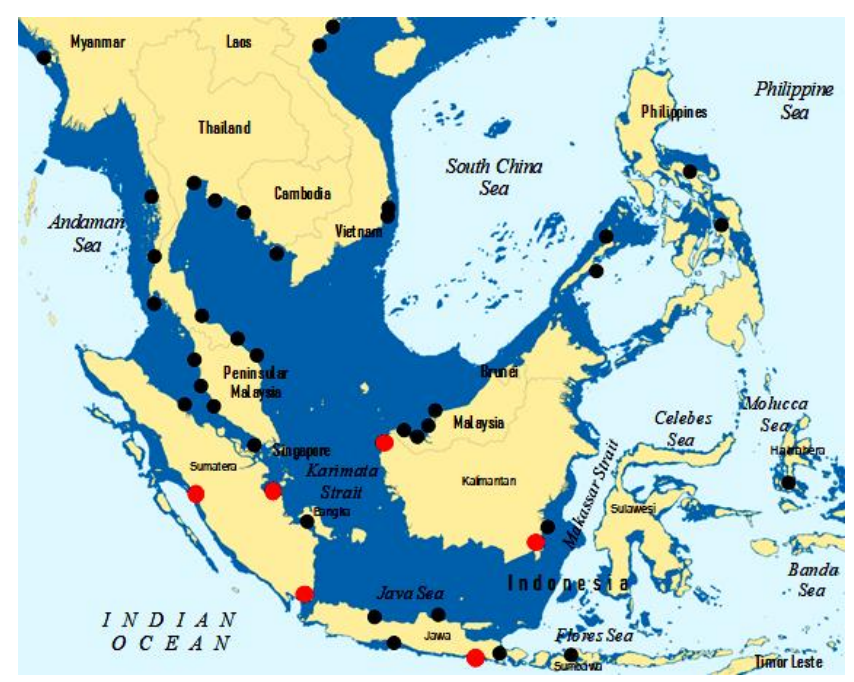

Figure 2. Jellyfish fisheries in Southeast Asia Brotz 2016)
The existence of scyphozoans in Saleh Bay has been known by fishermen since 2002, and began to be caught in 2006 as a fishing activity for fisher household income source (Asrial 2015). Asrial (2015) provides information that catching jellyfish using scoop net (fishing gear), and the mouth-arm of jellyfish are processed into semi-dried salted jellyfish on the coastal mainland of Saleh Bay (Asrial 2015). The fishing and processing activities of scyphozoan in Saleh Bay have a very large multiplier effect on the economic activities of coastal communities.

The problem of scyphozoan fisheries management in Saleh Bay is that the utilization rate reaches $92.65 \%$ (fully exploited), and the level of fishing gear use (163.49\%) exceeds the sustainable limit ( $f_{M S Y}$ ) (Asrial 2015). This study evaluates the sustainability status of scyphozoan fisheries management with a multidimensional approach (6 dimensions), namely biology, ecology, technology, economy, social/institutional, and ethics/regulations. A study of the utilization and management of edible jellyfish has been conducted in Indonesia with an approach of 3 aspects of utilization in Bali waters (LIPI 2012) and 5 dimensions of management in the Saleh Bay waters (Asrial 2015). The advantage of this study is that it generates management sustainability values and sensitive management attributes. These sensitive attributes form the basis for the preparation of action plans to increase the value and status of the sustainability of edible jellyfish fisheries management. This article, part of research using the Rapjellyfish-6D technique, describes and discusses two dimensions of the six dimensions of management, namely the technological dimension (input factor) and the economic dimension (output factor).

This study aims to provide an overview of the sustainability status of scyphozoan fisheries management in Saleh Bay, West Nusa Tenggara Province (NTB), Indonesia. The urgency is to present the sensitive attributes on economic and technological dimensions of jellyfish fisheries management.

\section{MATERIALS AND METHODS}

\section{Time and site of research}

Data collection was carried out for six months, from October 2018 to April 2019, except data on fishing technology and scyphozoan trade was collected in the period October-December 2018. The research was conducted in the coastal areas of Saleh Bay in Sumbawa Island (Indonesia), and several fishing centers around Saleh Bay (Figure 3). Saleh Bay area is located in the northern part and in the middle of Sumbawa Island, within the administrative area of Sumbawa and Dompu Districts.

The waters area is about $2,123 \mathrm{~km}^{2}$ with a maximum length and width of $86 \mathrm{~km}$ (46.46 nautical miles) and 36 $\mathrm{km}$ (19.50 nautical miles). The width of the mouth of the Bay is $23.5 \mathrm{~km}$ (12.71 nautical miles), 'clogged' by Moyo Island, which is located outside Saleh Bay (DKP NTB 2009). The length of the coastline of the Saleh Bay area is $561.1 \mathrm{~km}$, consisting of the coastline of the main island (P. Sumbawa) and small islands along $352.0 \mathrm{~km}$ and $209.1 \mathrm{~km}$. 
The typology of the coast consists of: (i) mangrove and swamp beaches $(195.3 \mathrm{~km})$, (ii) sandy beaches $(60.8 \mathrm{~km})$, and (iii) cliffs and rocky beaches (305.0 km) (DKP NTB 2009).

The waters of the Saleh Bay area are the estuaries of several rivers of the perennial and annual types, and most of them are intermittent rivers type. The main water source for Saleh Bay waters comes from the Flores Sea, north of the bay (Asrial 2015). The bathymetry model of Saleh Bay waters on the side of Sumbawa District does not have a regular pattern of depth. According to the National Marine Environment Map, the maximum depth of Saleh Bay waters reaches $324 \mathrm{~m}$ (DKP NTB 2009).

Based on the Schmidt-Ferguson climate classification, the area of Saleh Bay is categorized as having a climate type ' $F$ ', namely the 'Dry' climate type because the number of dry months (DM) is more than twice that of wet months (WM) (DM> 2WM). During the West Monsoon season, abundant rainfall occurs in January, February, March, and December. Meanwhile, very little rainfall occurs during the East Monsoon season, especially in June, July, August, and September.

The Scyphozoan became visible to the fishermen of Saleh Bay in September (Asrial 2015). The scyphozoan season runs from September to January, usually caught by fishermen during the October-December period. The peak fishing season occurs in December, which occurs in the waters east of Saleh Bay (Asrial 2015). This research activity, especially the collection of primary data on scyphozoan fisheries activities, is carried out during the scyphozoan fishing season which only lasts October to December each year.

\section{Data compilation method}

Data is compiled in the middle and the end of the month from October $1^{\text {st }}$ to December $30^{\text {th }}$ of 2018 , during the scyphozoan fishing season. During the scyphozoan fishing season, the authors visited the study site nine times (three times/month) to conduct sampling (measure and weigh) and collect other data. Another activity is to gather information about the phenomena and activities of scyphozoan fisheries. Sampling techniques were carried out to collect scyphozoan samples from fishermen, while documentation and dialogue techniques were employed to collect data through notes and recordings. Data (primary and secondary) were collected at Teluk Santong Fishing Port, the location of the largest scyphozoan fisheries center in the Saleh Bay area. Fishermen and boat owners (21 respondents) are Teluk Santong Village residents who operate 7 boats to catch the scyphozoan and sell the scyphozoan at the Teluk Santong Fishing Port.

Primary data were obtained by measuring, weighing, observing, interviewing, and recording techniques. Primary data relating to the technological dimensions collected include fishing gear, fishing vessels, scyphozoan collector/attractor, fishing grounds, fishing trips, ship engines, and fuel consumption. Other information collected includes navigation tools, fish finders, fish hold, and onboard fish processing activity. Primary data for the economic dimension include source of investment funds, the operational costs of catching scyphozoans, the price of scyphozoan mouth-arms, the production of scyphozoan mouth-arms per trip, scyphozoan market, income, profit, etc. Secondary data collected is time-series data consisting of scyphozoan production volume and number of scoop nets for 8 years (2009-2016) to estimate the sustainable potential and utilization status of scyphozoan resources.

\section{Research methods}

Data Analysis

Data analysis aims to estimate the utilization status of scyphozoan resources, the fisher's income levels, the business viability status, and the scyphozoan business sustainability status. Data analysis was carried out on scyphozoan production for the last eight years (2009-2016). The aim was to analyze the maximum sustainable yield (MSY) and the level of utilization.

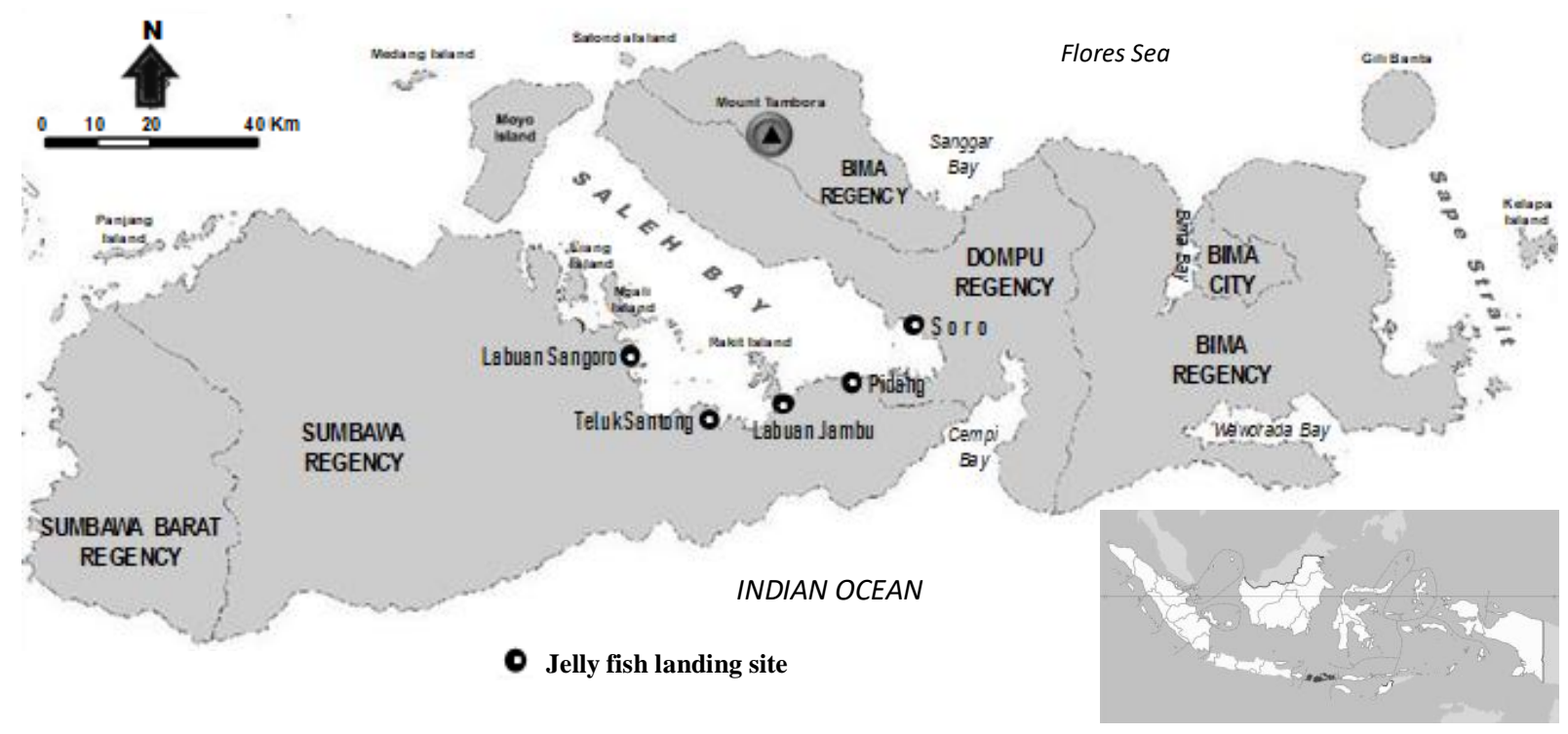

Figure 3. Map of Saleh Bay in West Nusa Tenggara Province, Indonesia 
Analysis of the utilization status of scyphozoan resources was done by addition of the previous year's production volume $\left(\mathrm{VP}_{2016}\right)$ to sustainable potential ( $\left.\mathrm{Y}_{\mathrm{MSY}}\right)$. Catch per unit effort (CpUE) and effort (f) data were processed with simple regression to obtain MSY value. Referring to the production surplus model (GordonSchaefer model) (Gordon 1954, Schaefer 1954), MSY consists of maximum production volume ( $\left.\mathrm{Y}_{\mathrm{MSY}}\right)$, maximum number of scoop/dip net ( $\left.f_{M S Y}\right)$, and maximum productivity $\left(\mathrm{U}_{\mathrm{MSY}}\right)$. The equations are as follows: $\mathrm{Y}_{\mathrm{MSY}}=$ $\mathrm{a}^{2} / 4 \mathrm{~b}, \mathrm{f}_{\mathrm{MSY}}=\mathrm{a} / 2 \mathrm{~b}$, and $\mathrm{U}_{\mathrm{MSY}}=\mathrm{a} / 2$, in which $\mathrm{a}=$ intercept, and $b=$ slope.

Values of $a b$ and were obtained from the simple regression result of catch per unit effort (CpUE) as the dependent variable, and effort (f) which signifies the number of scoop nets. The formulas are as follows: $\mathrm{CpUE}$ $=\mathrm{VP} / \mathrm{f}$ and $\mathrm{CpUE}=\mathrm{a}+\mathrm{b}_{\mathrm{i}} \mathrm{f}_{\mathrm{n}}$, in which: $\mathrm{CpUE}=$ productivity (kg/unit/year), $\mathrm{VP}=$ production volume $(\mathrm{kg} /$ year), and $\mathrm{f}=$ number of scoop net (units/year).

Utilization level (U) was obtained from a comparison of the previous year's production volume $\left(\mathrm{Y}_{2016}\right)$ with $\mathrm{Y}_{\mathrm{MSY}}$. The equation is: $\mathrm{U}=\left(\mathrm{Y}_{2016} / \mathrm{Y}_{\mathrm{MSY}}\right) \times 100 \%$. The rate was estimated using government policies implementing a total allowable catch $(\mathrm{TAC}): \mathrm{U}_{\mathrm{TAC}}=\mathrm{Y}_{2016} /\left(80 \% \mathrm{x} \mathrm{Y}_{\mathrm{MSY}}\right) \mathrm{x}$ $100 \%$. The standard status of scyphozoan fisheries resource utilization (U) consists of (Dwiponggo 1987): Unexploited/EU (U = 0-25\% MSY), (b) Lightly Exploited/LE (U $=>25-50 \%$ MSY), (c) Moderately Exploited/ME $(\mathrm{U}=>50-75 \% \quad \mathrm{MSY}), \quad(\mathrm{d})$ Fully Exploited/FE (U = >75-100\% MSY), (e) Overfishing/OF $(\mathrm{U}=>100 \% \mathrm{MSY})$, and (f) Depletion/D = drastically decreasing production.

Scyphozoan fisheries business analysis cover cost, profit $(\pi)$, business feasibility, revenue per cost ratio $(\mathrm{R} / \mathrm{C}$ Ratio), and break-even point (BEP). BEP is calculated using the price and production volume approach. Total cost (TC) analysis ( $\mathrm{TC}=\mathrm{FC}+\mathrm{VC}$ ) is obtained by adding the fixed cost (FC) to variable cost (VC) in the currency units (IDR). Total revenue (TR) equals transaction value (TV). TR analysis equals the multiplication of total production (TP) and selling price $(\mathrm{P})$. The formula is $\mathrm{TR}=\mathrm{TP} \times \mathrm{P}$. The profit analysis of a business is the difference between TR and TC. If the value is positive, it is called 'profit', and if negative, it is called 'loss'. The equation is written as: $\pi=$ TR - TC, in which: $\pi=$ profit (IDR/year), $\mathrm{TR}=$ total revenue (IDR/year), and $\mathrm{TC}=$ total cost (IDR/year). If $\pi$ is positive, then the business is profitable, and if $\pi$ is negative, it signifies loss. In addition, if $\pi$ is zero, then the business is even (no profit and no loss).

The profit margin ratio (PMR) analysis aims to discover the level of business profit. It can be calculated with this equation: $\mathrm{PMR}=\{(\mathrm{TR}-\mathrm{TC}) / \mathrm{TC}\} \times 100 \%$. R/C analysis aims to ascertain the profitability of the business (or loss) of a business. It is calculated by adding the total revenue to the total cost. The formula is $\mathrm{R} / \mathrm{C}=\mathrm{TR} / \mathrm{TC}$, in which: $\mathrm{R}=$ revenue (IDR), $\mathrm{C}=$ cost (IDR), $\mathrm{TR}=$ total revenue (IDR), and $\mathrm{TC}=$ total cost (IDR). To determine the feasibility of the business, it must meet the following criteria: $\mathrm{R} / \mathrm{C}>1.0$ $=$ profit, $\mathrm{R} / \mathrm{C}<1.0=$ loss, and $\mathrm{R} / \mathrm{C}=1.0=$ break even. Break-even point (BEP) analysis is an analytical technique collating information about a situation where the operational activities of the business/company neither result in profit nor losses (Sunyoto 2013). In this study, $\mathrm{BEP}$ is calculated based on the price $\left(\mathrm{BEP}_{\mathrm{P}}\right)$ and production volume $\left(\mathrm{BEP}_{\mathrm{VP}}\right) \cdot \mathrm{BEP}_{\mathrm{P}}=\mathrm{TC} / \mathrm{VP}$, in which: $\mathrm{BEP}_{\mathrm{P}}=$ price $\mathrm{BEP}(\mathrm{IDR} / \mathrm{kg}), \mathrm{TC}=$ total cost $(\mathrm{IDR})$, and $\mathrm{VP}=$ production (basket). Meanwhile $\mathrm{BEP}_{\mathrm{VP}}=\mathrm{TC} / \mathrm{P}$ in which: $\mathrm{BEP}_{\mathrm{VP}}=$ production $\mathrm{BEP}(\mathrm{kg}), \mathrm{TC}=$ total cost $(\mathrm{IDR})$, and $\mathrm{P}=$ price (IDR/basket).

Marketing fishery products are the key to develop a fishery business (Triyanti and Safitri 2012). Scyphozoan marketing activities are economic processes and activities that determine the fluctuations in prices, demand, and supply of goods and services. The marketing chain of fishery products will affect the quality of commodities (freshness), costs, efficiency, profits (losses), and income. The condition for marketing and chains is the presence of high production by actively involving several institutions. Scyphozoan marketing activities in Saleh Bay at least include producer, buyer, and financial institutions.

\section{Sustainability Analysis}

Management sustainability analysis is carried out on the technological and economic dimensions. The aim is to discover the sensitive attributes which interfere with the value of sustainable management. The analysis employed the Rapjellyfish-6D technique developed from Rapjellyfish (Asrial et al. 2015b) due to the modified Rapfish (Pitcher et al. 1998). The type of analysis used consists of:

Feasibility test of the model: obtained from the results of RAP Analysis that measures: (i) determination/influence by observing the value of R Square (Multiple R), and (ii) the standard deviation measured from the Stress value. According to Fauzi and Anna (2005), the recommended stress value is a maximum of $0.25(\leq 25.0 \%)$ so that model deviation can still be tolerated/accepted.

The value of management sustainability: obtained from RAP Analysis data for each attribute of management dimension. Management sustainability criteria are divided into: (i) not sustainable/NS $(<0.25)$, (ii) less sustainable/LS $(>0.25-0.50)$, (iii) moderately sustainable/MS ( $>0.50 \quad-$ 0.75 ), and (iv) sustainable/S (>0.75-1.00) (Susilo 2003; Asrial et al. 2015b).

Sensitivity test of attribute: obtained from the Leverage Analysis results used in the form of the value of each management attribute for each management dimension. The greater the value, the smaller the contribution to the sustainability of management and the greater the contribution to the sustainability of management.

\section{RESULTS AND DISCUSSION}

\section{Production and productivity (CpUE)}

Scyphozoan production in Saleh Bay comes from fishing activities using fishing equipment conducted by small fishermen. They use the scoop net, in which one fisherman operates each unit. Each scyphozoan fishing boat consists of 3 fishermen for 3 units of scoop net per boat. There is no need to standardize the scoop net because 
fishermen only use the scoop net to catch the scyphozoan in Saleh Bay.

During the period 2009-2016, the increased number of scoop nets were used, which indicates that the number of fishermen catching scyphozoan has also increased and scyphozoan fishing has intensified. In 2009, the scoop net totaled 25,597 units which produced 86,105 tons of scyphozoan mouth-arm, with a catch per unit effort (CpUE) or productivity of 3.364 tons/unit/year. In 2016, the number of scoop nets was 36,333 units and produced 170.16 tons of mouth-arm, resulting in CpUE 4.683 tons/unit/year. The highest CpUE occurred in 2014, which was 8.076 tons/unit/year. At that time, the number of scoop nets was not the most during 2009-2016. The largest number of scoop net in 2013 was 38,810 units, which decreased by 10,690 units $(27.54 \%)$ in 2014 .

The conversion results of the scyphozoan mouth-arm production in 2016 as many as $170,166,157.90 \mathrm{~kg}$ came from the $577,437.59$ tons of scyphozoan. The biomass is identical to $412,652,932.91$ individuals of scyphozoan resources. The above estimation corroborates with Asrial (2015), who reported that every $1.0 \mathrm{~kg}$ of scyphozoan mouth-arm in Saleh Bay sourced from $3.42 \mathrm{~kg}$ or 2,42 individual scyphozoan resources.

\section{Status of resources stock/reserve}

Estimation of stocks of fish resources (henceforth: FR) in waters puts forward the following assumptions: (a) FR stock is spread evenly in these waters, (b) all FR catch data obtained from the water area, (c) all catches landed in the area, and (d) the level of fishing technology did not experience significant changes during the data collection period (Cushing 1981; Sparre 1998). The same is true for guessing the stock of scyphozoan resources.

From the results of data processing with simple regression, it is obtained that the values of $\mathrm{a}=6.55590$ and $\mathrm{b}=-0.00006$. Thus, the model is CpUE $=6.55590$ 0.00006 scoop net, and a negative equation pattern. The model means that each addition of 1.0 unit of scoop net will decrease CpUE by the scoop net constant value.

These results are used to interpret the amount of scyphozoan resource reserves. With the Gordon-Schaefer approach (Gordon 1954, Schaefer 1954), it is estimated that scyphozoan stock (biomass) $=377,739.80$ tons, $\mathrm{Y}_{\mathrm{MSY}}=$ $188,869.90$ tons/year, $\mathrm{f}_{\mathrm{MSY}}=57,618$ units/year, and $\mathrm{CpUE}_{\mathrm{MSY}}=3.278$ tons/unit/year. Asrial (2015) estimated that the sustainable potential of scyphozoan resources in the Saleh Bay area is 33,261.18 tons/year or identical with $8,159,179,680-8,975,097,648$ individuals/year.

\section{Level and status of utilization}

Referring to the surplus production model of GordonSchaefer (Gordon 1954, Schaefer 1954), the production ratio to the estimated potential for scyphozoan sustainability results in a utilization rate of $90.09 \%$ in 2016 . Thus, its utilization status is 'Fully Exploited/FE' (> 75$100 \%)$. This utilization status is the same as the utilization status in 2013 ( $\mathrm{Y}_{2013}$ ), except that the utilization rate is slightly smaller than in 2013 (Asrial 2015). In this status, it is not recommended to add production units because it will decrease CpUE.

Confirmation of the utilization status of fish resources is also carried out following the provisions of the Indonesian government that apply the amount of total allowable catch (TAC) which is $80 \%$ of the sustainable potential (TAC $=80 \% \mathrm{MSY}$ ). The sustainable potential of scyphozoan resources based on TAC $\left(\mathrm{Y}_{\mathrm{TAC}}\right)$ is 151,095.92 tons/year, which indicates that the utilization rate is $112.62 \%$, and utilization status is 'Overfishing/OF' (more than $100 \%$ MSY). The operating level of the scoop net is still far below the recommended threshold ( $\left.f_{2016}<f_{M S Y}\right)$. Whereas productivity in $2016\left(\mathrm{CpUE}_{2016}\right)$ has far exceeded the allowed threshold $\left(\mathrm{CpUE}_{2016}>\mathrm{CpUE} \mathrm{MSY}_{\mathrm{S}}\right)$.

A paradoxical situation has occurred in the management of scyphozoan resources in the waters of Saleh Bay. This condition is caused by the level of use of scoop net which is still below standard (low) but can produce utilization status up to FE and OF, while the CpUE has exceeded the limit. This fact occurs because some fishermen operate more than one fishing trip in one night. If the mean CpUE is ascribed to $\mathrm{CpUE}_{\mathrm{MSY}}$ the result is $143.09 \%$. It is estimated that $43.09 \%$ of scoops are operated more than once per night during the scyphozoan fishing season.

\section{Agribusiness status of scyphozoan fisheries}

Small fishermen carry out scyphozoan fishing activities in Saleh Bay. The activities begin at the beginning of the rainy season during the October-December periods. The fishermen use a wooden boat equipped with an onboard engine. To catch scyphozoans use scoop net, and lamps/lights are used to attract and collect scyphozoans.

Scoop net is a type of fishing gear that is not selective because the mesh size is smaller than the scyphozoan body; thus, the tool is incapable of capturing the size of a scyphozoan that is worth to be processed. This fishing gear's selectivity actually lies with the fishermen because they can opt a worthy scyphozoan; like its umbrella or hat with a diameter of at least $18.0 \mathrm{~cm}$ (Asrial 2015).

This scyphozoan agribusiness being continuously done from 2006 and later it was stopped for two years in 2017 and 2018 because the buyers from Surabaya did not come to Saleh Bay. The scyphozoan agribusiness's main actors are boat owners and fishermen as producers from the Saleh Bay, Bima and Sumbawa areas. Another major actor who plays a very important role is the collector traders from Surabaya (East Java) who act as buyers, processors, and exporters of scyphozoan.

Each boat, which is majority manned by three fishermen, can catch and sell 8-30 baskets of scyphozoan mouth-arms at an average price of IDR 50,000 per basket. Transaction value (TR) IDR 400,000-1,500,000 or average IDR 950,000/trip. Each trip (TC) cost is around IDR 200,000 , in which fuel costs IDR 125,000 and logistics costs IDR 75,000. The difference between the transaction value and the cost is divided into 5 (five) parts. The distribution is two parts for boat owners and equipment, and each one is for fisher (average of 3 fishermen/boat). If operational costs reduce the transaction value, there is a balance of IDR 750,000. 
Thus, each fisherman gets a share of approximately IDR $150,000 /$ trip or a total of IDR 3,750,000 per month (25 fishing days). The boat owner gets 3 shares of the profit from ownership of the boat and fishing gear as well as fishermen, so that the income reaches IDR 450,000/trip or IDR $11,250,000 /$ month (25 fishing days). This income is much higher than the NTB provincial minimum wage standard for labor.

Based on the analysis of business profits above, it is found that the $\mathrm{R} / \mathrm{C}$ Ratio $=4.75$ which means a profit rate of $475.00 \%$ per night. This value means that every scyphozoan fishery businessman spends IDR 1.00, then receives IDR 4.75 or earns a profit of IDR 3.75. According to the eligibility criteria, when $\mathrm{R} / \mathrm{C}>1.0$, the scyphozoan fisheries business is declared feasible to be continued. Thus, the scyphozoan fishing business is feasible to be continued and developed (Soekartawi 1995).

Data processing produces $\mathrm{BEP}_{\mathrm{P}}=$ IDR 13,158.00/ basket. As the price is IDR $80,000 /$ basket, the $\mathrm{BEP}_{\mathrm{VP}}=$ 3.13 baskets/trip. If it is assumed to be the lowest price (IDR 30,000/basket), then $\mathrm{BEP}_{\mathrm{VP}}=8.33$ baskets/trip. Thus, scyphozoan fisheries entrepreneurs have achieved profits because they exceed $\mathrm{BEP}_{\mathrm{P}}$ and $\mathrm{BEP}_{\mathrm{VP}}$ values. It can be concluded that the BEP analysis is the acquisition of business processes in one period without being able to print rent/profit and not suffer losses. It can also be perceived as a balance between the value of the transaction with business costs, or only able to return the cost/venture capital.

\section{Scyphozoan commodity marketing system}

Fresh mouth-arm of the scyphozoan sold to buyers or processors after meeting a price agreement. The price is determined unilaterally by the buyer, who also acts as a scyphozoan processor. The sales system is direct without brokers. Fishermen receive coupons from buyers after "weighing" of scyphozoan. The coupon reads "the value of the scyphozoan sales transaction" and it can be exchanged for money by fishermen in the afternoon.

The scyphozoan marketing system has a very short in line, from producers to consumers. As a result, the profit received by fishermen is maximum. However, this system becomes weak for fishermen because the buyer unilaterally determines the price. In consequence, the type of scyphozoan commodity market is the oligopsony market: many producers (fishermen) and few consumers (buyers). This type of market is detrimental to fishermen because the buyer's price is always below the equilibrium point and the fisher actually loses some part of his profits (lost some profit).

\section{Management sustainability status}

Evaluation of the sustainability of scyphozoan fisheries resource management in Saleh Bay was approached through the technological and economic dimensions. The technological dimension (13 attributes) reflects the production subsystem (Table 1). Whereas the economic dimension (14 attributes) explains the marketing subsystem (Table 2). Data processing uses the Rapjellyfish-6D technique, which results in the sustainability value of each dimension and the value of each attribute of the above two dimensions.

The RAP Analysis results (Table 3) are useful for the test model shown by the R Square (determination) value of the technological dimension of $93.52 \%$ and the economic dimension of $95.30 \%$. This value indicates that all attributes together are very strong in determining (> 80\%) the formation of management sustainability values. While the stress value (standard deviation) of the technological and economic dimensions are $13.50 \%$ and $12.91 \%$, respectively. Stress value $<25 \%$ means that model deviations that occur are still acceptable (tolerated) (Fauzi and Anna 2005). Thus, the model can be used for forecasting in the context of planning.

Table 1. Technological dimension of jellyfish fisheries management in Saleh Bay Waters, Sumbawa Island, Indonesia

\begin{tabular}{|c|c|c|c|c|c|}
\hline Dimension/attribute & Bad & Good & Scale/score & $\begin{array}{l}\text { Data/fact/ } \\
\text { information }\end{array}$ & Score \\
\hline Jellyfish fishing gear & 0 & 2 & $0=$ Active $; 1=$ Mixture $; 2=$ Passive & Scoop net & 0 \\
\hline $\begin{array}{l}\text { The environment friendlines } \\
\text { of fishing gear }\end{array}$ & 0 & 2 & $\begin{array}{l}0=\text { Damaging; } 1=\text { Note damaging; } 2= \\
\text { Environment friendly }\end{array}$ & Environment friendly & 2 \\
\hline Fishing gear selectivity & 0 & 2 & $0=$ Note selective $; 1=$ Mixture $; 2=$ Selective & Selective & 0 \\
\hline Side effects of fishing gear & 0 & 3 & $0=$ Large $; 1=$ Medium $; 2=$ Small $; 3=$ None & None & 3 \\
\hline Fish finder & 0 & 2 & $\begin{array}{l}0=\text { None } ; 1=\text { Available and not operating; } 2= \\
\text { Available and operated }\end{array}$ & None & 0 \\
\hline Navigation facilities & 0 & 2 & $\begin{array}{l}0=\text { None } ; 1=\text { Available and not operating; } 2= \\
\text { Available and operated }\end{array}$ & $\begin{array}{l}\text { Available and } \\
\text { operated }\end{array}$ & 2 \\
\hline Boat size & 0 & 3 & $0=<12 \mathrm{~m} ; 1=12-17 \mathrm{~m} ; 2=>17-24 \mathrm{~m}$ & $7-9 \mathrm{~m}$ & 0 \\
\hline Fishing trip & 0 & 2 & $0=>30$ days; $1=7-30$ days $; 2=1-7$ days & 1 day & 2 \\
\hline Availabolity of fish hold & 0 & 2 & $0=$ None $; 1=$ Portable $; 2=$ Permanent & None & 0 \\
\hline Type of fish hold & 0 & 1 & $0=$ Non insulator $; 1=$ Insulator & Non insulator & 0 \\
\hline Fish preservation process & 0 & 5 & $\begin{array}{l}0=\text { Not done } ; 1=\text { Fumigation; } 2=\text { Drying } ; 3= \\
\text { Salting } 4=\text { Freeing } ; 5=\text { Cooling }\end{array}$ & Not done & 0 \\
\hline Fish processing before sale & 0 & 2 & $0=$ Not done $; 1=$ Some done $; 2=$ Done & Done & 2 \\
\hline Jellyfish landing place location & 0 & 2 & $\begin{array}{l}0=\text { Centralized } ; 1=\text { Sometimes centralized } ; 2= \\
\text { Scattered }\end{array}$ & 7 places & 2 \\
\hline
\end{tabular}


The sustainability of the management regarding both technological and economic dimensions accounted for $36.13 \%$ and $49.64 \%$, respectively (Figure 4). According to Susilo (2003), the status of management for both dimensions is less sustainable. The management value for the economic dimension is near to the status of moderately sustainable ( $>50-75 \%$ ). The sustainability of management value formation is influenced by all management attributes with different levels of influence. Figure 5 shows that the value of each attributes the value of each attribute from the leverage analysis results. The greater the value of the attribute, the smaller its effect on the sustainability of management, or the greater the effect on the unsustainability of management. The aim is to establish the sensitive attributes of each management dimension that cause low sustainability value.

Table 2. Economic dimension of jellyfish fisheries management in Saleh Bay Waters, Sumbawa Island, Indonesia

\begin{tabular}{|c|c|c|c|c|c|}
\hline Dimension/Attribute & Bad & Good & Scale/score & $\begin{array}{c}\text { Data/fact/ } \\
\text { information }\end{array}$ & Score \\
\hline Source of fishing capital & 0 & 3 & $0=$ Bank; $1=$ Own equity; $2=$ Famliy; $3=$ Non bank & Own equity & 1 \\
\hline Fishing business status & 0 & 2 & $0=$ Individual $; 1=$ Business entity $; 2=$ Cooperative & Individual & 0 \\
\hline Scale of fishing effort & 0 & 3 & $0=$ Micro $; 1=$ Small $; 2=$ Medium $; 3=$ Big & Micro & 0 \\
\hline Target of fishing effort & 0 & 2 & $0=$ Part Time $; 1=$ Seasonal $; 2=$ Full & October-december & 1 \\
\hline Income of fishermen & 0 & 2 & $0=\langle\mathrm{UMR} ; 1=\mathrm{UMR} ; 2=>\mathrm{UMR}$ & IDR 5.0/month & 2 \\
\hline Price of target fish (Rp/ton) & 0 & 5 & $\begin{array}{l}0=<2.7 \text { million; } 1=2.7-12.15 \text { million; } 2=12.15- \\
20.25 \text { million; } 3=20.25-40.50 \text { million; } 4=40.50- \\
67.5 \text { million; } 5=>67.5 \text { million }\end{array}$ & Rp. 3.0 million & 1 \\
\hline Business profit (R/C Ratio) & 0 & 2 & $\begin{array}{l}0=\operatorname{Loss}(\mathrm{R} / \mathrm{C}<1) ; 1=\text { Breakeven }(\mathrm{R} / \mathrm{C}=1) ; 2= \\
\text { Profit }(\mathrm{R} / \mathrm{C}>1)\end{array}$ & 1.72 (profit) & 2 \\
\hline Type of market & 0 & 3 & $\begin{array}{l}0=\text { Public market } ; 1=\text { Mixed market } ; 2=\text { Fish } \\
\text { market; } 3=\text { Hygienic fish market }\end{array}$ & Fish market & 2 \\
\hline Target of market & 0 & 3 & $0=$ Local $; 1=$ Provincial $; 2=$ National $; 3=$ Regional & Local & 0 \\
\hline System of market & 0 & 4 & $\begin{array}{l}0=\text { Monopoly; } 1=\text { Oligopoly; } 2=\text { Monopsony; } 3= \\
\text { Oligopsony; } 4=\text { Competition market }\end{array}$ & Oligopsony & 3 \\
\hline Scale of market & 0 & 2 & $0=$ Traditional $; 1=$ Modern $; 2=$ Drying $; 3=$ Hygienic & Traditional & 0 \\
\hline The shap of the market & 0 & 2 & $0=$ Online $; 1=$ Abstract $; 2=$ Real & Real market & 2 \\
\hline Market schedule & 0 & 4 & $\begin{array}{l}0=\text { Temporary; } 1=\text { Annualy } ; 2=\text { Monthly; } 3=\text { Weekly; } \\
4=\text { Daily }\end{array}$ & Annualy & 1 \\
\hline Profit transfer & 0 & 2 & $0=$ Greater external $; 1=$ Equivalent $; 2=$ Greater internal & Greater internal & 2 \\
\hline
\end{tabular}

Table 3. Rapjellyfish-6D analysis result of jellyfish fisheries management in Saleh Bay

\begin{tabular}{|c|c|c|c|c|c|}
\hline \multirow{2}{*}{ Dimension } & \multicolumn{2}{|c|}{$\begin{array}{l}\text { Sustainability } \\
\end{array}$} & \multirow[t]{2}{*}{ Stress $(\%)$} & \multirow[t]{2}{*}{ R Square (\%) } & \multirow[t]{2}{*}{ Sensitive Attribute } \\
\hline & Value (\%) & Status & & & \\
\hline Technological dimension & 36.13 & Less sustainable & 13.50 & 93.52 & 5 \\
\hline Economic dimension & 49.64 & Less sustainable & 12.91 & 95.29 & 3 \\
\hline
\end{tabular}

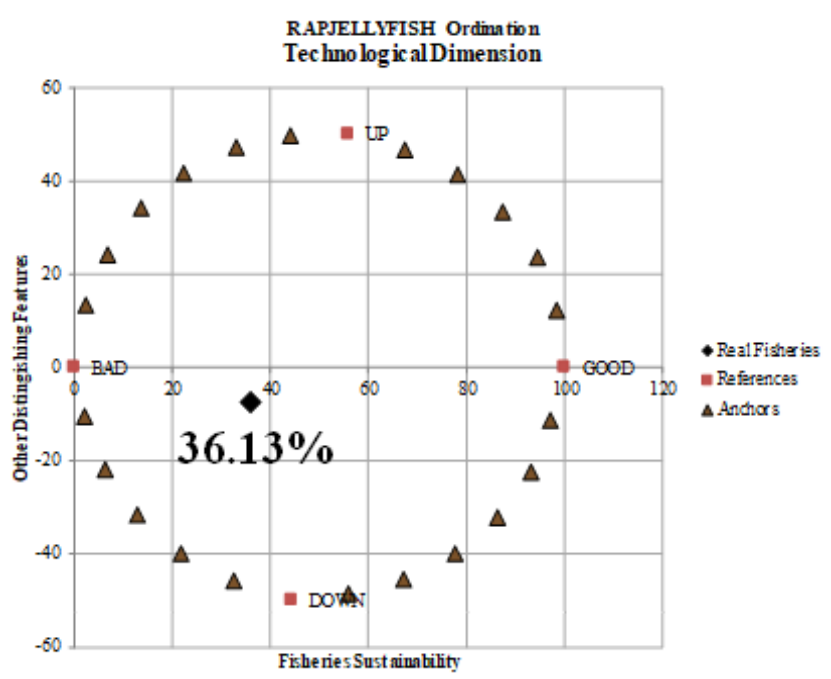

A

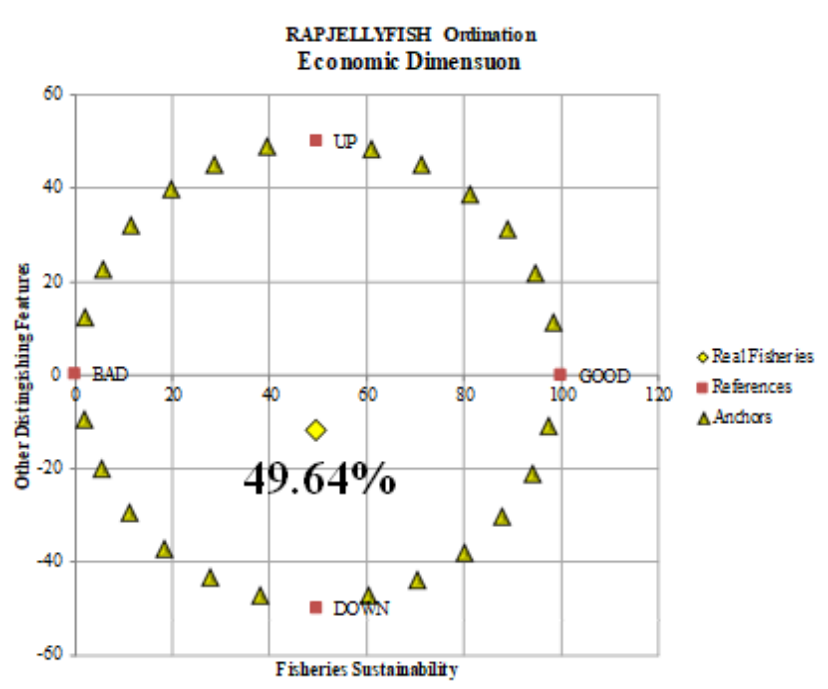

B

Figure 4. The sustainability value of jellyfish fisheries management in Saleh Bay, West Nusa Tenggara, Indonesia. A. Technological dimension, B. Economic dimension. 

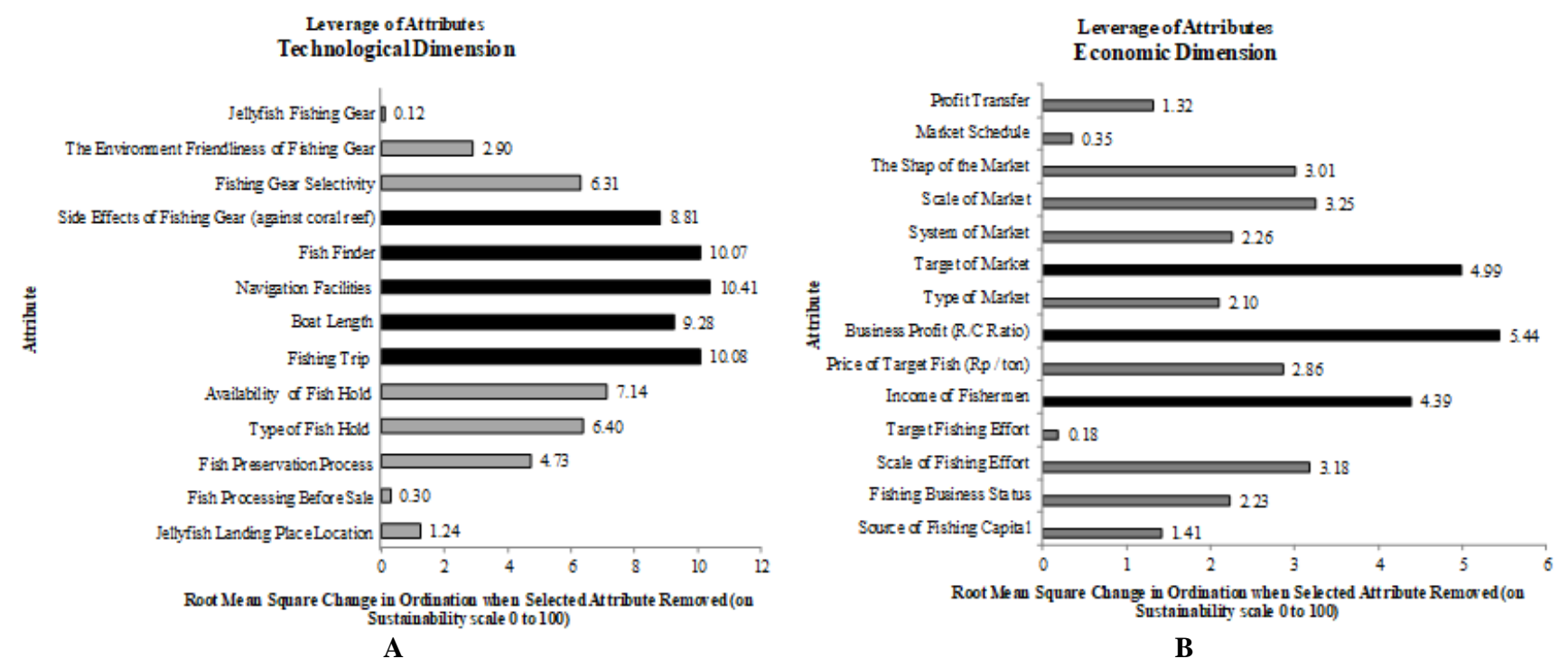

Figure 5. Sensitive attributes on jellyfish fisheries management in Saleh Bay (black = sensitive attribute). A. Technological dimension, B. Economic dimension.

On the technology dimension, predictions state that there is a maximum of 5 sensitive attributes, out of 13 $(38.46 \%)$. Meanwhile, as many as 3 , out of $14(21.43 \%)$ economic dimensions are classified as sensitive attributes. Overall, there were 8 sensitive attributes from 27 management attributes (29.63\%). The types of problematic/sensitive attributes consist of: (1) Technological Dimension (5 attributes): Fishing Trip, Boat Length, Navigation Facilities, Fish Finder, and Side Effect of Fishing Gear (against coral reef), and (2) Economic Dimension (3 attributes): Income of Fishermen, Business Profit, and Target Market. Leverage analysis was used to improve the sustainability status of management by intervening in the sensitive attributes of choice (Asrial et al. 2017). With sustainability and sensitive attributes, it is necessary to improvise the value of sustainable management for scyphozoan fisheries in the Saleh Bay through the intervention of sensitive attributes.

In conclusion, the management of the scyphozoan fishery in Saleh Bay began in 2006. Until the end of 2018, the scyphozoan biomass in the waters of Saleh Bay was estimated at $377,739.80$ tons. The utilization rate reaches $90.10 \%$, level of scoop net usage is $63.06 \%$, productivity (CpUE) is $142.88 \%$, and the level of profit (R/C Ratio) is 4.75. The utilization status of the scyphozoan resources in Saleh Bay is 'Fully Exploited'. Meanwhile, the sustainability level of management of the technology dimension (36.13\%) and the economic dimension (49.64\%) have the status of 'Less Sustainable'. This result becomes a paradox when scyphozoan's fishermen' income is higher than the regional minimum wage of West Nusa Tenggara Province in 2019 of IDR 2,013,000 per month. Thus, the existence of scyphozoan fisheries resources in Saleh Bay's waters has boosted fisher's household income, and boosted the economic improvement of the coastal communities of Saleh Bay.
To improve the management's sustainability status, the parties need to intervene with sensitive attributes. For scyphozoan fisheries management activities to be sustainable, the village government needs to build a scyphozoan processing facility on the coastal lands of Saleh Bay. The facility guarantees buyers, processors and exporters of scyphozoan from Surabaya to come to Saleh Bay every scyphozoan fishing season.

\section{ACKNOWLEDGEMENTS}

The authors of this article thanks the DRPR DJPRP Ministry of Research, Technology, and Higher Education for funding this publication based on applied research activities. Its continued proposal number is 0899/L8/KM/2019 dated March 27, 2019, both the head of LLDIKTI Region VIII and the Rector of University 45 of Mataram.

\section{REFERENCES}

Asrial E, Hamid, Marzuki M. 2018. Edible Jellyfish: Character of the Resource and Habitat. Mitra Usaha, Bogor. [Indonesian]

Asrial E, Prajitno A, Susilo E, Bintoro G. 2015a. Biology and blooms of the Edible Jellyfish (Crambione mastigophora) in the Saleh Bay, Indonesia. J Biodivers Environ Sci 6 (6): 356-369.

Asrial E, Prajitno A, Susilo E, Bintoro G. 2015b. Rapjellyfish method to evaluate the sustainability status of edible jellyfish resource management in Saleh Bay, Indonesia. Intl J Recent Sci Res 6 (7): 5190-5198.

Asrial E, Prajitno A, Susilo E, Bintoro G. 2017. Edible jellyfish resource: A model of community-based coastal fisheries management. Intl $\mathbf{J}$ Recent Sci Res 8 (1): 15055-15061.

Asrial E. 2015. Sustainable management model of jellyfish resources of Crambione mastigophora in Saleh Bay, West Nusa Tenggara. [Dissertation]. University of Brawijaya, Malang. [Indonesian] 
Brotz L, Cheung WWL, Kleisner K, Pakhomov E, Pauly D. 2012. Increasing jellyfish populations: Trends in large marine ecosystems. Hydrobiologia 690: 3-20.

Brotz L, Pauly D. 2012. Jellyfish populations in the Mediterranean Sea. Acta Adriatica 53 (2): 211-230.

Brotz L. 2016. Jellyfish fisheries of the world. [Doctoral Dissertation]. The University of British Columbia, Vancouver.

Condon RH, Graham WM, Duarte CM, Pitt KA, Lucas CH, Haddock SHD, Sutherland KR, Robinson KL, Dawson MN, Beth Decker M, Mills CE, Purcell JE, Malej A, Mianzan H, Uye S, Gelcich S, Madin LP. 2012. Questioning the rise of gelatinous zooplankton in the World's Oceans. BioScience 62: 160-169.

Cushing DH. 1981. Fisheries Biology, A Study in Population Dynamics. The University of Wisconsin Press, London.

Dwiponggo A. 1987. Indonesia's Marine Fisheries Resources. Indonesian Marine Captures Fisheries. ICLARM and Directorate General of Fisheries, Jakarta. [Indonesian]

Fauzi A, Anna S. 2005. Modeling of Fisheries and Marine Resources. Gramedia Pustaka Utama, Jakarta. [Indonesian]

Gordon HS. 1954. The economic theory of a common-property resource: the fishery. J Polit Econ 62\{ 124-142.

Keesing JK, Gershwin L, Trew T, Strzelecki J, Bearham D, Liu D, Wang Y, Zeidler W, Onton K, Slawinski D. 2016. Role of winds and tides in timing of beach strandings, occurrence, and significance of swarms of the jellyfish Crambione mastigophora Mass 1903 (Scyphozoa: Rhizostomeae: Catostylidae) in north-western Australia. Hydrobiologia 768: 19-36. DOI: 10.1007/s10750-015-2525-5.

LIPI, 2012. Technology for the Utilization of Edible Jellyfish Fisheries in Bali Waters. Indonesian Institute of Sciences (LIPI), Jakarta. [Indonesian]

Manuputty AEW. 1988. Jellyfish (Scyphomedusea) and how to process them. Oseana 13 (2): 49-61.
Miranda LS, Morandini AC, Marques AC. 2012. Do staurozoa bloom? A review of Stauromedusan population biology. Hydrobiologia 690: 5767.

Omori M, Nakano E. 2001. Jellyfish fisheries in southeast Asia. Hydrobiologia 451: 19-26.

Perissinotto R, Taylor RH, Carrasco NK, Fox C. 2013. Observations on the Bloom-forming Jellyfish Crambionella stuhlmanni (Chun 1896) in the St. Lucia Estuary, South Africa. Afr Invertebr 54 (1): 161-170.

Pitcher TJ, Mackinson S, Vasconcellos M, Nùttestad L, Preikshot D. 1998. Rapid Appraisal of the Status of Fisheries for Small Pelagics Using Multivariate, Multidisciplinary Ordination. In: Quinn II TJ, Funk F, Heifetz J, Ianelli JN, Powers JE, Schweigert JF, Sullivan J., Zhang CI (eds) Fishery Stock Assessment Models. Alaska Sea Grant, Fairbanks, USA.

Schaefer M. 1954. Some aspects of the dynamics of populations important to the management of the commercial marine fisheries. Bull. InterAmerican Trop. Tuna Comm. 1: 27-56.

Schroeder R, Branco JO, Freitas Jr F, Resgalla Jr C. 2014. Preliminary Assessment of the Jellyfish Bycatch Captured of Southern and Southeastern Brazil. Latin Am J AquatRes 42 (2): 289-300.

Soekartawi. 1995. Farm Business Analysis. UI Press, Jakarta. [Indonesian]

Sparre P. 1998. Introduction to tropical fish stock assessment. Part 1: manual. FAO Fish Tech Paper 306: 1-407.

Sunyoto D. 2013. Analysis of Financial Statements for Business: Theory and Cases. CAPS, Yogyakarta. [Indonesian]

Susilo SB. 2003. Sustainability of Small Island Development: Case Study of Panggang Island and Pari Island Villages, Seribu Islands, DKI Jakarta. [Dissertation, Unpublished]. IPB Postgraduate School, Bogor. [Indonesian]

Triyanti R, Shafitri N. 2012. Study of Catfish Marketing (Clarias sp.) in Supporting Aquaculture Industry (Case study in Boyolali District, Central Java). Ministry of Marine Affairs and Fisheries, Jakarta. [Indonesian] 